\title{
Are Students Ready to Adopt E-Portfolio? Social Science and Humanities Context
}

\author{
Syamsul Nor Azlan Mohamad ${ }^{1}$, Mohamed Amin Embi ${ }^{1} \&$ Norazah Mohd Nordin ${ }^{1}$ \\ ${ }^{1}$ Department of Teaching \& Learning Innovation, Universiti Kebangsaan Malaysia, Malaysia \\ Correspondence: Syamsul Nor Azlan Mohamad, Department of Teaching \& Learning Innovation, Universiti \\ Kebangsaan Malaysia, Malaysia. E-mail: snazlan@siswa.ukm.edu.my
}

Received: January 26, 2015 Accepted: March 20, 2015 Online Published: May 16, 2015

doi:10.5539/ass.v11n13p269 URL: http://dx.doi.org/10.5539/ass.v11n13p269

\begin{abstract}
This paper presents the learners readiness towards the implementation of E-Portfolio as means of solving the persistent problems in educational setting. The purpose of the study was to examine the learner's readiness towards the implementation E-Portfolio in higher education. Initially, this paper was conducted a study with a total number of 300 students form Social Sciences and Humanites cluster and then practicing portfolio in their coursework. The pilot study was conducted and showed the reliability coefficient with Cronbach's alpha $(\alpha)$ is 0.825. The instrument was divided into five components which involved (1) technology accessibility (2) online skills and relationship (3) motivation (4) internet discussion and (5) importance to success, to measure the learners' readiness. The findings were reported that students are ready to have an E-Portfolio as a learning tool in constructing their knowledge and experience of learning. The E-Portfolio will extend the opportunity from paper-based into the electronic based with a variety of online learning features in gaining students interest and motivation in learning. At the end of the day, the E-Portfolio will not only benefit the students and the faculty but also towards the employability.
\end{abstract}

Keywords: E-Learning, E-Portfolio, online learning, online readiness, ICT, teaching and learning, higher education, learning management

\section{Introduction}

Electronic portfolio or known as E-Portfolio is one of new range of educational instrument has been seen gradually implemented in a few higher education institutions for curriculum, teaching content and assessment. Commonly, the E-Portfolio is not only used as a support tool for teaching and learning but also as a preparation for job hunting.

In higher education, students are developing E-Portfolio as an evidence-based and assessment to support their learning needs. (Michelson \& Mandell, 2004; Baume \& Yorke, 2002; De Rijdt, Tiquet, Dochy, \& Devolder, 2006; Klenowski, Askew, \& Carnell, 2006; Seldin, 1997; Wolf, 1991; Wright, Knight, \& Pomerleau, 1999). This argument supported by Love et al., (2004) stated that learning technique involves instruction and evaluation has a significant effect on education. (Lopez-Fernandez \& Rodriguez-Illera, 2009; Chang et al., 2011). Instead of paper-based, most of the higher institutions here been using E-Learning as a medium of teaching and learning due to the potential and the benefit of technologies.

Creative applications in ICT have a very high potential to change the educational process to support higher order thinking skills among learners. However, the evidence is still limited in data. The role and potential of ICT in bringing major changes in the education system cannot be questioned. The increase in numeral, sophistication, and the role of ICTs in providing rich and effective tools to transform teaching and learning are more autonomous and entertaining.

In the Malaysian context, E-Portfolio is seen as a potential learning support to solve a persistent problem for teaching and learning in higher education (Campbell, Melenyzer, Nettles, \& Wyman, 2000; Palomba \& Banta, 2001; Chapman et al., 2001; Clark \& Eynon's, 2009; Li \& Kunglin Wang, 2010) underlying the national policy and agency (PPIM, 2013; MQA, 2013). Although, E-Portfolio has been developed in many countries and fields, there is little research focused on it (Woelfel, 2012; Tariq \& Khalid, 2013). Due to DeFabio (1993); Jamentz (1994) and Tillema (1998) statement that the proponents of portfolio are better predictors in assessing and 
improving students' cognitive (Chin Hung, 2013) especially higher order thinking (HOTs) skills specifically in higher education institution (Gikandi et al., 2011). In Malaysia context, Amin Embi (2010) was highlighted 90\% of a HIE's are looking forward to extend the use of E-Learning including by having E-Portfolio in their system. Unfortunately, to date, there is a little research, which has shown the existence of E-Portfolio.

The author believes that a proper strategy is urgently needed and followed by the national policy to encourage the utilization of emerging technologies with E-Learning. The findings show that more than half or $50 \%$ of the HEI's have their online courses and blended learning is the most popular practiced (Amin Embi et al., 2011). At this juncture, ideally the E-Portfolio should be introduced as an innovation of $21^{\text {st }}$ century learning to extend the level of accessibility.

\section{Literature Review}

\subsection{E-Portfolio Definition}

Since the 1990s, the use of E-Portfolios is gradually increasing significant in higher education institutions. Two reasons why E-Portfolio has been chosen because of the constructive approach to education which emphasizes learning by experience and the potential of computer technology in education to support the facilitator and learner (Meeuse, Quiestier \& Derks, 2006). Meeuse et al. (2006) defined a portfolio as a pieces of artwork collection as a method for demonstrating or showing a person's best work. The learners have kept portfolios for a crertain time and period with the intent to exhibit the efforts, work experience, and life achievement or evidences (Silvia, 2011; Barrett, 2007; Rogers \& Chow, 2000; Zheng, 2009). However, Barrett (2007) went further in defining and believed that portfolio should prioritze on the learning and reflection to enable learner to exchange the idea and feedback (Lorenzo \& Ittleson, 2005). Hence, with the help of E-Portfolio as an innovation of instructional tool, facilitator is able to evaluate learner reflection to develop higher order thinking skills (Clark \& Eynon, 2009). As to conclude, E-Portfolio is a collection of authentic and dynamic (Thomas et al., 2001) documentation of a learner's progress includes learning, assessment and reflection (Moon, 2004; Sharma \& Mishra, 2006; Li \& Wang, 2010) to support formal, informal and non-formal learning (Balaban et al., 2012) anywhere and at any time (Holmes \& Gardner, 2006).

\subsection{The Nature}

In a Social Science and Humanities cluster at Universiti Teknologi MARA consists five faculties (1) Faculty of Education (2) Faculty of Art and Design (3) Faculty of Music (4) Faculty of Mass Media and Communication and lastly (5) Faculty of Film, Theater and Animation who practicing E-Portfolio as a routine in formative assessment. It also followed by the standard of assessment has been proposed by Malaysia Qualification Accreditation or known as MQA as a guideline in assessing students in higher education institution especially for art and design courses. So that, the portfolio become an important formative assessment evidences to places and manage their visual art and design projects, researching, relating knowledge, and becoming committed to ongoing professional development and critical thinking, as they learn to collect, display, articulate, evaluate and communicate their ideas in this technical platform (Sturrock \& Earley, 2007).

\subsection{Are We Ready?}

There is still little research conducted and claims to support such argument (Ayala, 2006; Hartnell-Young \& Morriss, 2007; Tosh et al., 2005). The previous findings did not reveal learners' learning benefited from using E-Portfolio. The past literature only discussed about the student learning dependency from the point of lecturers view on belief of E-Portfolio (Acker, 2005; Barrett \& Carney, 2005; Cambridge et al., 2001; Jafari \& Kauffman, 2006; Tosh et al., 2005; Yancey, 2001; Zubizaretta, 2004). Considering the use of E-Portfolio at the HEIs, it is still limited regardless that almost all HEIs in Malaysia use an E-Learning system as a support tool to engage and collaborate with the learners. The preliminary study needs to be conducted to investigate the learner's readiness towards the use of E-Portfolio in their coursework. The learner's readiness was measured based on five components consisted (1) technology accessibility (2) online skills and relationships (3) motivation (4) internet discussion (5) the importance of success. These components will the implementation of the E-Portfolio in future.

\section{Methodology}

The purpose of this study is to investigate the learner's readiness towards the use of E-Portfolio in their coursework. At this stage, Faculty of Education, Faculty of Art and Design, and Faculty of Film, Theater and Animation has been chosen with a total number of respondents 300 students. These respondents who undergoing Bachelor of Art and Design Education, that who are practicing coursework. The questionnaire was adapted from 1) the E-Learning Readiness by Mark Rosenberg (2000) and 2) The Online Readiness Self-Assessment Instrument by Watkins (2003). It is consists two (2) sections. Section A asked about the demographic profile and 
Section B was measured learner's readiness. These items were measured on five-point Likert scale ranging from (1) strongly disagree, (2) disagree, (3) neutral, (4) agree and (5) strongly agree.

\section{Data Analysis and Findings}

\subsection{Respondent's Profile}

In this study, simple frequency and descriptive analysis was conducted on the demographic attributes. Table 1 present the descriptive result of the respondent's profiles. As reported in the table, 33.1\% $(\mathrm{n}=107)$ were male and $60.1 \%(n=194)$ of the respondents were female. In terms of ages grouping, almost half $44.2 \%(n=143)$ with average $22-23$ years, $37.5 \%(n=121) 20-21$ years, $9.3 \%(n=30) 24-25$ years and $1.9 \%(n=6) 25$ years above. The frequency of the internet usage was take account to saw the tendencies of the respondents maximizing the facilities, as stated $71.5 \%$ respondents were active and very often used the internet and followed by $23.3 \%$ extremely often and $18.9 \%$ of the respondents in a moderate level. Based on this report, the number shown equally wire access with $47.4 \%$ of the students surfing the internet using on-campus mode compare than $45.2 \%$ is on-campus.

Table 1. Frequency of demographic respondents

\begin{tabular}{lll}
\hline Demographic Attributes & Frequency & \% (Percentage) \\
\hline Gender & 107 & 33.1 \\
Male & 194 & 60.1 \\
Female & & \\
Age & 1 & 0.3 \\
$18-19$ years & 121 & 37.5 \\
$20-21$ years & 143 & 44.3 \\
$22-23$ years & 30 & 9.3 \\
$24-25$ years & 6 & 1.9 \\
25 years above & & \\
Wireless & 153 & 47.4 \\
On-campus & 146 & 45.2 \\
Off-campus & & \\
Internet Usage & 1 & 0.3 \\
Not at all & 8 & 2.5 \\
Slightly often & 61 & 18.9 \\
Moderate & 134 & 41.5 \\
Very often & 97 & 30.0 \\
Extremely often &
\end{tabular}

Table 2. Contructs involves in learners readiness towards the use of E-Portfolio

\begin{tabular}{lll}
\hline No. & Constructs & Mean \\
\hline 1 & Technology Accessibility & 4.11 \\
2 & Online Skills and Relationships & 4.08 \\
3 & Motivation & 3.50 \\
4. & Internet Discussions & 3.89 \\
5. & Importance to Your Success & 4.00 \\
\hline
\end{tabular}

\subsection{Technology Accessibility}

The first constructs of this study were reported there is a need to have access to a computer with adequate software $(m=4.33)$. The accessibility merely is more important when the computer occupied with an Internet connection $(m=4.16)$. However, this report also stated that the hardware meet-up a standard and requirement is a way to avoid the disruption when students access the technology $(m=3.88)$. 


\subsection{Online Skills and Relationships}

The second construct's to saw the online skills and its relationships towards the use of E-Portfolio. Before the implementation of E-Portfolio, the students need to empower an online skill to help them to manage the resources. Based on this report, self-online management such emailing $(m=4.48)$, basic skills in operating a computer $(m=4.25)$ and information searching $(m=4.25)$ will ensure the success to prolong with the E-Learning. Secondly, the students are comfortable using computer several times a week to participate in a course $(m=4.14)$, then its allowed students to ask question $(m=3.94)$, and enable to reflect via online tools (e.g., email, chat) either synchronous or asynchronous time to work on assignments with students $(m=4.04)$. There are a students used a few strategy such providing a commenting column is very helpful $(m=3.83)$ to them, an emoticon expression of thoughts and feelings $(m=3.81)$, and at the end followed by facilitating responses to another $(m=3.70)$.

\subsection{Motivation}

For this construct's shown a moderate mean for all items. Mostly students depend on the instructor to motivate them along the teaching and learning process via online by possible $(m=3.54)$. Somehow, students faces an on-screen distraction that enable them to complete the work or assignment $(m=3.53)$ and also the surrounding might affect the motivation $(m=3.40)$.

\subsection{Internet Discussions}

This construct's was reported the Internet discussion is the convenience way to carry on the conversation $(m=4.14)$ and they agreed it's the effective ways of learning. However, some of the students are needed more time allocation to prepare themselves to responses a question $(m=3.91)$ and they willing scaffolds with an online conversation $(m=3.82)$. In another point, shown the students relatively more participative joined the disussion even the instructor might not be able to join together.

\subsection{Importance to Your Success}

Online learning will be succeed if the learner knows the importance. The students felt that prior experiences with online technologies (e.g., email, Internet chat, online readings) are important to their success with online course $(m=4.07)$. Despite, technical and administrative support $(m=4.04)$ and course material available in online system $(m=4.03)$ throughout the learning process are very important to their success in online coursework. That will influence the instructor support to sustain and used online learning for seeks of their benefits $(m=3.94)$ and the frequencies of participation $(m=3.88)$.

\section{Conclusion and Implication}

Based on this findings, there are five constructs was discussed the learners readiness in different perspectives involved (1) technology accessibility (2) online skills and relationship (3) motivation (4) internet discussion and (5) importance to success. The learner's readiness is to ensure students need to be occupied with a certain basic skills and to allow them fully utilize the online learning before implementing the E-Portfolio. The E-Portfolio can be utilized to analyze and assess student's work. This study concludes there is a need to highlight the concept and ability of E-Portfolio in collecting, managing, grading, recalling and reflecting (Batson, 2002). Portfolios tend to offer a better holistic picture of student understands, since they hold more than one piece of evidence, rather than the traditional one-time assessment such as a test, paper, or project. At the end, Portfolios allow the students to become responsible and invest in their own education (Jarvinen \& Kohonen, 1995; Krause, 1996; Ross, 1996; Smith \& Tilemma, 2001; Sturrock \& Early, 2007; Thomas et al., 2001). Instructor and administrator is the key support to ensure students prolong the interest and benefit the use of online learning. The specific learning strategy and instructional design need to be consider increasing their motivation and intention. Electronic portfolios should serve as excellent holding places for student reflections because of their ability to be viewed by faculty, students, administration, future employers, and to whomever the student chooses to share that particular portfolio.

\section{Limitations and Future Research}

The limitation of this study, whereas the samples not cater the whole population of a Social Science and Humanities cluster. This study could benefit the early stage on justifying the reliability of the instrument. Therefore, there is a need the instrument to be tested to make sure it's reliable and could be used in the actual fieldwork. The current study still has it limitation in term of sampling techniques. Therefore, for future study, it is very important to determine preferable sampling techniques to match with the requirement and represent the population of the study. 


\section{References}

Acker, S. (2005). Overcoming obstacles to Authentic E-portfolio Assessment. Campus Technology. Retrieved from http://campustechnology.com/Articles/2005/03/Overcoming-Obstacles-to-Authentic-ePortfolio-Assess ment.aspx? $\mathrm{p}=1$

Ally, M. (2004). Foundations of Educational Theory for Learning. Athabasca University.

Ayala, J. (2006). Electronic Portfolios for Whom? Educause Quarterly, 29(1), 12-13.

Balaban, E. Mu., \& Divjak, B. (2012). Development of an Electronic Portfolio system success model? An information systems approach. Computers \& Education, 60, 396-411. http://dx.doi.org/10.1016/j.compedu. 2012.06.013

Barett, H. (2007). Researching Electronic Portfolios and Learner Engagement: The REFLECT Initiative. Journal of Adolescent \& Adult Literacy, 50(6), 436-449. http://dx.doi.org/10.1598/JAAL.50.6.2

Barrett, H. C. (2005). White paper: Researching electronic portfolios and learner engagement: The REFLECT initiative researching electronic portfolios. Learning engagement and collaboration through technology. Retrieved from http://www.taskstream.com/reflect/whitepaper.pdf

Baume, D., \& Yorke, M. (2002). The reliability of assessment by portfolio on a course to develop and accredit teachers in higher education. Studies in Higher Education, 27(1), 7-25. http://dx.doi.org/10.1080/0307507 0120099340

Bixby, J., Glenn, J., Gardner, H., \& Wolf, D. (1991). To use their minds well: Investigating new forms of assessment. Review of Research in Education, 17(3), 26-30.

Cambridge, B. L., Kahn, S., Tompkins, D. P., \& Yancey, K. B. (Eds.). (2001). Electronic portfolios: Emerging practices in student, faculty and instructional learning. American Association for Higher Education.

Campbell, D. M., Melenyzer, B. J., Nettles, D. H., \& Wyman, R. M. (2000). Portfolio and performance assessment in teacher education. Boston: Allyn \& Bacon.

Chang, C. S., \& Ku, D. T. (2011). A Framework of PBL Strategy Integrated in LMS and a Ubiquitous Learning Environment. Journal of Convergence Information Technology, 6(4).

Chapman, P., Fames-Moore, M., Szczygiel, M., \& Thompson, D. (2000). Building internet capabilities in SME. Logistics Information Management, 13(6), 353-360. http://dx.doi.org/10.1108/09576050010355662

Chin-Hung, L., Shu-Ching, Y., \& Chin-Chi, L. (2013). Support as a Mediator of the Impact of Cognitive Load on Students' E-Portfolio Learning Outcomes. Social Behavior \& Personality: An International Journal, 41(1), 17-30. http://dx.doi.org/10.2224/sbp.2013.41.1.17

Clark, J. E., \& Eynon, B. (2009). E-Portfolios at 2.0-surveying the field. Peer Review, 11(1), 18-23.

De Rijdt, C., Tiquet, E., Dochy, F., \& Devolder, M. (2006). Teaching portfolios in higher education and their effects: An explorative study. Teaching and Teacher Education, 22(8), 1084-1093. http://dx.doi.org/10. 1016/j.tate.2006.07.002

DeFabio, R. (1993). Characteristics of student performance as factors in portfolio assessment. ERIC Document Reproduction Service No. ED 355556.

Embi, M. A. (2011). E-Learning in Malaysian Higher Education Institutions: Status, Trends, \& Challenges. Department of Higher Education Ministry of Higher Education.

Embi, M. A., \& Norazah. (2013). Mobile Learning: Malaysian Initiatives \& Research Findings. Centre For Academic Advancement, Universiti Kebangsaan Malaysia \& Department of Higher Education, Ministry of Higher Education.

Field, A. (2009). Discovering Statistics using SPSS. London: Sage.

Gikandi, J. W., Morrow, D. D., \& Davis, N. E. (2011). Online formative assessment in higher education: A review of the literature. Computers \& Education, 57(4), 2333-2351. http://dx.doi.org/10.1016/j.compedu. 2011.06.004

Hartnell-Young, E., \& Morris, M. (Eds.). (2007). Digital portfolios: Powerful tools for promoting professional growth and reflection (2nd ed.). Thousand Oaks, CA: Corwin Press.

Holmes, B., \& Gardner, J. (2006). E-Learning: Concepts and practice. Thousand Oaks, CA: Sage Publishing.

Jafari, A., \& Kaufman, C. (2006). Handbook of Research on Eportfolios, 1, 648. 
Jamentz, K. (1994). Making sure that assessment improves performance. Educational Leadership, 51(6), 55-57.

Jarvinene, A., \& Kohonen, V. (1995). Promoting professional development in higher education through portfolio assessment. Assessment \& Evaluation in Higher Education, 20(1), 25-36. http://dx.doi.org/10.1080/0260 293950200104

Klenowski, V., Askew, S., \& Carnell, E. (2006). Portfolios for learning, assessment and professional development in higher education. Assessment and Evaluation in Higher Education, 31(3), 267-286. http://dx.doi.org/10.1080/02602930500352816

Krause, S. (1996). Portfolios in teacher education: Effects on pre-service teachers' early comprehension of the portfolio process. Journal of Teacher Education, 47(2), 130-138. http://dx.doi.org/10.1177/0022487196047 002006

Kukulska-Hulme, A., \& Traxler, J. (2007). Designing for mobile and wireless learning. In H. Beetham, \& R. Sharpe (Eds.), Rethinking Pedagogy for a Digital Age: Designing and Delivering E-Learning (pp. 180-192). London: Routledge.

Li, L., \& Wang, K. L. (2010). The Design and Implementation of E-Portfolio based Performance Assessment System in E-Learning. 2010 International Conference on E-Business and E-Government. http://dx.doi.org/ 10.1109/ICEE.2010.1393

Lopez-Fernandez, O., \& Rodriguez-Illera, J. L. (2009). Investigating university students' adaption to a digital learner course portfolio. Computers \& Education, 52, 608-616. http://dx.doi.org/10.1016/j.compedu. 2008.11.003

Love, \& Cooper. (2004). Designing Online Information Systems for Portfolio-Based Assessment: Design Criteria and Heuristics. Journal of Information Technology Education, (3).

Meeus, W., Questier, F., \& Derks, T. (2006). Open source eportfolio: Development and implementation of an institution-wide electronic portfolio platform for students. Educational Media International, 43(2), 133-145. http://dx.doi.org/10.1080/09523980600641148

Michelson, E., \& Mandell, A. (Eds.). (2004). Portfolio Development and the Assessment of prior learning. Sterling, VA: Stylus.

Mishra, P., \& Koehler, M. J. (2006). Technological pedagogical content knowledge: A framework for teacher knowledge. Teachers College Record, 108(6), 1017-1054. http://dx.doi.org/10.1111/j.1467-9620.2006. 00684.X

Moon, J. A. (2004). A handbook of reflective and experiential learning: Theory \& Practice. London: Routledge Falmer.

Palomba, C. A., \& Banta, T. W. (Eds.). (2001). Assessing student competence in accredited disciplines: Pioneering Approaches to Assessment in Higher Education. Sterling, VA: Stylus.

Pelan Pembangunan Pendidikan Malaysia. (2013-2025). Kementerian Pendidikan Malaysia.

Riggs, I. M., \& Sandlin, A. (2000). Teaching Portfolios for Support of Teachers' Professional Growth. NASSP Bulletin, 84(618), 22-27. http://dx.doi.org/10.1177/019263650008461804

Rogers, G., \& Chow, T., (2000). Electronic portfolios and assessment of student learning. Assessment Update, 12(1), 12-16.

Ross, E. W. (1996). The role of portfolio evaluation in social studies teacher education: How evaluation practices shape learning experiences. Social Education, 60(3), 162-166.

Seldin, P. (1997). The teaching portfolio: A practical guide to improved performance and promotion/tenure decisions (2nd ed.). Bolton, MA: Anker.

Sharma, R. C., \& Mishra, S. (Eds.). (2006). Cases on Global E-Learning practices (pp. 95-107). Hershey, PA: Information Science Publishing.

Smith, K., \& Tillema, H. (2001). Long-term influences of portfolios on professional development. Scandinavian Journal of Educational Research, 45(2), 183-203. http://dx.doi.org/10.1080/00313830120052750

Sturrock, D., \& Early, C. (2007). Mahara E-Portfolio system implementation case study. Retrieved from http://eduforge.org/docman/view.php/176/1516/AUT\%20ePortfolio\%20Implementation\%20Case\%20Study. pdf.Thomas 
Thomas, K. R., Lamson, S., \& King, A. (2001). Training teacher candidates to create web-based electronic professional portfolios. Paper presented at Central Missouri State University's Department of Curriculum and Instruction.

Tillema, H. H. (1998). Design and validity of a portfolio instrument for professional training. Studies in Educational Evaluation, 24(3), 263-278. http://dx.doi.org/10.1016/S0191-491X(98)00017-0

Tosh, D., Light, T. P., Fleming, K., \& Haywood, J. (2005). Engagement with electronic portfolios: Challenges from the student perspective. Canadian Journal of Learning and Technology, 31(3). Retrieved from http://www.cjlt.ca/index.php/cjlt/article/view/97/91

Woelfel, K., Murray, K., \& Page, M. (2014). Electronic Portfolios for Professional Educators-Graduate Students and Instructors. International Journal of Instructional Media, 37(2), 175-183.

Wolf, K. (1991). The schoolteacher's portfolio: Issues in design, implementation, and evaluation (pp. 129-136). Phi Delta Kappan.

Wright, W. A., Knight, P. T., \& Pomerleau, N. (1999). Portfolio people: Teaching and learning dossiers and innovation in higher education. Innovative Higher Education, 24(2), 89-103. http://dx.doi.org/10.1023/ B:IHIE.0000008148.71650.e6

Yancey, K. B. (2001). Digitized student portfolios. In B. L. Cambridge, S. Kahn, D. P. Tompkins, \& K. B. Yancey (Eds.), Electronic portfolios: Emerging practices in student, faculty, and institutional learning (pp. 15-20). Washington, DC: American Association for Higher Education.

Zubizaretta, J. (2004). The learning portfolio. Bolton, MA: Anker Publishing.

\section{Copyrights}

Copyright for this article is retained by the author(s), with first publication rights granted to the journal.

This is an open-access article distributed under the terms and conditions of the Creative Commons Attribution license (http://creativecommons.org/licenses/by/3.0/). 